\title{
The Case for Special Juries in Complex Civil Litigation
}

It is difficult to imagine a less appropriate mechanism for the determination of facts in a protracted and complicated suit than the civil jury. ${ }^{1}$

The common sense of the common man . . . cannot be brought to bear unless there is comprehension of the facts and the law.

With these words an experienced practitioner and the Chief Justice of the United States expressed their concern over one of the major issues of modern judicial administration: can juries render satisfactory verdicts in lengthy, complicated cases? Questions about the abilities of civil juries have been raised by courts, ${ }^{3}$ scholars, ${ }^{4}$ practicing attorneys, ${ }^{5}$ and the press. ${ }^{\circ}$ Many believe that juries are ill-equipped to understand the factual and legal issues involved in complex business litigation. Defenders of the jury, however, contend not only that jury trials are preferable to bench trials, ${ }^{7}$ but also that denying the right to a jury trial is, in many cases, unconstitutional. ${ }^{8}$

This debate has focused on the choice between trial by a traditional jury and trial by a judge alone. $A$ third alternative has not received the attention it deserves: a trial could be conducted before a special jury of persons chosen especially for their ability to understand a protracted

1. Kirkham, Complex Civil Litigation-Have Good Intentions Gone Awry? 70 F.R.D. 199, 208 (1976).

2. Nat'l L.J., Aug. 13, 1979, at 21, col. 1 (reporting and quoting in part address by Chicf Justice Warren Burger to the Conference of State Chief Justices (Aug. 7, 1979)).

3. E.g., ILC Peripherals Leasing Corp. v. International Business Machs. Corp., 458 F. Supp. 423, 444, 447 (N.D. Cal. 1978); In re Boise Cascade Sec. Litigation, 420 F. Supp. 99, 104 (W.D. Wash. 1976).

4. E.g., Redish, Seventh Amendment Right to Jury Trial: A Study in the Irrationality of Rational Decision Making, 70 Nw. U.L. Rev. 486, 505 (1975); Comment, The Right to an Incompetent Jury: Protracted Commercial Litigation and the Seventh Amendment, 10 CoNN. L. REv. 775, 783-86 (1978).

5. E.g., Campbell, A Historical Basis for Banning Juries, Nat'1 L.J., Feb. 11, 1980, at 17, col. 1; Kirkham, supra note 1, at 207-09.

6. E.g., Work, Are Jurors Smart Enough? Nat'l L.J., Dec. 31, 1979, at 1, col. 1; Shaffer, Those Complex Antitrust Cases, Wall St. J., Aug. 29, 1978, at 16, col. 4.

7. E.g., Zenith Radio Corp. v. Matsushita Elec. Indus. Co., 478 F. Supp. 889, 934-35 (E.D. Pa. 1979); Higginbotham, Continuing the Dialogue: Civil Juries and the Allocation of Judicial Power, 56 Tex. L. Rev. 47, 53 (1977).

8. E.g., In re U.S. Financial Sec. Litigation, 609 F.2d 411, 432 (9th Cir. 1979), cert. denied, 48 U.S.L.W. 3694 (U.S. April 28, 1980) (No. 79-1383); Zenith Radio Corp. v. Matsushita Elec. Indus. Co., 478 F. Supp. 889, 942 (E.D. Pa. 1979). 
and complex case. Although the special jury has been suggested as a possible solution to some of the problems of trying a complicated case, it has not been adequately discussed. ${ }^{9}$ In particular, no commentator has demonstrated that special juries can meet the constitutional requirements of the Seventh Amendment or of the due process clause. This Note provides that analysis and proposes that Congress amend the federal Jury Selection and Service Act of $1968^{10}$ to allow the use of special juries in certain complex cases.

The Note outlines the difficulties of trying complex cases and discusses ways in which special juries are superior to judges or traditional juries for the resolution of such matters. Examining the constitutional dimensions of trial by a special jury, the Note demonstrates that, for the trial of complex cases, the special jury more nearly approaches the

9. Several recent discussions of the use of juries in complex civil litigation mention the special jury as an alternative to a traditional jury trial or a bench trial. The constitutional and practical problems presented by the special jury, however, have not been in. vestigated, nor have any specific proposals been developed. See, e.g., Harris \& Liberman, Can the Jury Survive the Complex Antitrust Case? 24 N.Y.L. ScH. L. Rev. 611, 634-36 (1979) (discussing special juries as alternative to wholesale elimination of juries in complex cases, but with only passing mention of historical background, constitutional questions, or practical difficulties); Note, The Right to a Jury Trial in Complex Civil Litigation, 92 HaRv. L. REv. 898, 915-17 (1979) (same); Note, The Right to Trial by Jury in Complex Litigation, 20 WM. \& MARY L. Rev. 329, 352 (1978) (suggesting amendment of Jury Selection and Service Act to allow use of special juries in order to increase jury competence in complex cases, but no discussion of constitutional concerns).

Proposals for special juries previously appeared in the 1940s, but they failed to attract significant support. In 1941, a discussion draft of the Revised Uniform Sales Act proposed "merchant jury" trials to determine special issues of "mercantile fact" in disputes governed by the Act. The merchant jury was not to resolve issues of liability, but merely render "special verdicts" to be received in evidence at the "general trial." See National Conference of Commissioners on Uniform State Laws, Report on a Revised Uniform SALES Act $\$$ 51-C \& Comments on $\$$ 51-C (1941). Following the conference of Commissioners on Uniform State Laws in September of that year, the advisory character of the proposed "merchant jury" was made clear in the National Conference of Commissioners on Uniform State Laws, Revised Uniform Sales act, Second Draft \$ 59-D (1941). The "merchant jury" became "merchant experts," and the jury was specifically authorized to disregard the "special findings" if necessary. The differences between the language of the discussion draft and that of the published version may be attributable to the drafters' recognition of constitutional objections to their proposal. Id. at Comment on $\S 59-\mathrm{D}$.

Other commentators also have suggested the use of special juries. See, e.g., Baker, In Defense of the "Blue Ribbon" Jury, 35 Iowa L. Rev. 409 (1950); Thatcher, Why Not Use the Special Jury? 31 MinN. L. REv. 232 (1947). Although the historical background in these articles generally is good, their consideration of Seventh Amendment and duc process issues is limited. This Note will address both the historical and constitutional dimensions of the case for using special juries.

10. 28 U.S.C. $\$ \S 1861-1875$ (1976). The Jury Selection and Service Act sets out specific means for selecting and summoning juries. In its current form, the Act would not allow the measures necessary to choose special jurors. Possibilities for amending the Act to permit the selection of special jurors are outlined in Part III of this Note. See pp. 1174. 76 infra. 
constitutional ideals of fairness, competence, and impartiality than does the traditional jury. The Note concludes by setting forth constitutionally acceptable procedures for selecting and administering special juries and suggests ways in which the special jury can be a partial solution to the problems posed by complex civil litigation. ${ }^{11}$

\section{The Problems of Juries in Complex Civil Litigation}

The burdens that complex, protracted litigation places on the federal courts $^{12}$ have brought the institution of the civil jury under attack. Juries have been criticized for being incapable of returning fair and rational decisions in complicated business cases. ${ }^{13}$ First, it is argued that the technical, legal, and economic concepts that arise in much business litigation are beyond the experience or understanding of the average juror. ${ }^{14}$ Moreover, it has been observed that jurors who may be better prepared by education or experience to understand such issues are more likely to be challenged for cause and excused at the voir dire stage of the proceedings. ${ }^{15}$

Second, it is contended that the very size of the trials in complex

11. This Note proposes only that special juries be employed in complex civil litigation in the federal courts. The Seventh Amendment right to a jury trial in civil cases has not been incorporated into the Fourteenth Amendment, see Melancon v. McKeithen, 345 F. Supp. 1025 (E.D. La. 1972), aff'd sub nom. Davis v. Edwards, 409 U.S. 1098 (1973), and Hill v. McKeithen, 409 U.S. 943 (1972), and thus the states may modify the civil jury so long as the requirements of due process are observed, id.; see pp. 1166-72 infra.

12. Between 1962 and 1978 the total number of trials completed per year in the federal district courts increased from 10,048 to 18,851. [1978] Director of the Administrative OfFice of the UNited States Courts ANN. ReP. Table 60, at 262. The number of jury trials per year lasting 20 days or more doubled from 40 in 1972 to 80 in 1978. Id. Table 61, at 263. In $1978,34 \%$ of the trials lasting four days or more were antitrust matters. Id. at 264.

13. See p. 1155 supra.

14. At the completion of one protracted civil trial, the federal district judge stated:

Throughout the trial, the court felt that the jury was having trouble grasping the

concepts that were being discussed by the expert witnesses, most of whom had doctorate degrees in their specialties. This perception was confirmed when the court questioned the jurors during the course of their deliberations and after they were discharged. When asked by the court whether a case of this type should be tried to a jury, the foreman of the jury said, "If you can find a jury that's both a computer technician, a lawyer, an economist, knows all about that stuff, yes, I think you could have a qualified jury, but we don't know anything about that."

ILC Peripherals Leasing Corp. v. International Business Machs. Corp., 458 F. Supp. 423, 447 (N.D. Cal. 1978) (quoting transcript at 19,548).

15. In one major antitrust case, SCM Corp. v. Xerox Corp., 463 F. Supp. 983 (D. Conn. 1978), 84 potential jurors appeared for jury selection. Twenty-two of those had occupational backgrounds identifiable as relevant to the case, such as managers, supervisors, scientists, or engineers. All 22 were excused for cause. Comment, supra note 4, at 778-80; cf. Work, supra note 6, at 11, col. 4 (statements by Los Angeles Superior Court Judge Julius Title that jurors with special expertise are weeded out in voir dire). 
litigation renders jury determination inappropriate. Untutored jurors may have great difficulty in digesting the massive amounts of evidence presented in complicated cases $^{16}$ and in resolving the conflicting claims and counterclaims of a large number of parties. ${ }^{17}$ In addition, the length of many complex trials reduces the effectiveness of the jury by making jury service an excessive burden. ${ }^{18}$

The alternative to trying complex cases before a traditional jury ordinarily is assumed to be trial by a judge alone. ${ }^{19}$ Recently, however, some judges themselves have expressed doubt that a judge can perform better than a jury in deciding complicated questions of fact. ${ }^{20}$ The collective wisdom and experience of a jury is said to be equal if not superior to that of a single judge. ${ }^{21}$ The presence of a jury forces attorneys to refine their arguments, marshal the facts, and make effective presentations, ${ }^{22}$ an incentive that often is lost in the less structured

16. See, e.g., ILC Peripherals Leasing Corp. v. International Business Machs. Corp., 458 F. Supp. 423 (N.D. Cal. 1978). In this case, 87 witnesses testified and more than 2,300 exhibits were admitted in a trial consuming 96 trial days. The transcript for the trial filled more than 19,000 pages. After 19 days of deliberation the jury was hopelessly deadlocked and the court declared a mistrial. $I d$. at 444 . The court directed a verdict for the defendant but struck a demand for a jury trial in the event the decision was remanded for retrial. Id. at 448 .

17. See, e.g., In re U.S. Financial Sec. Litigation, 75 F.R.D. 702, 705-06, 715 (S.D. Cal. 1977), rev'd, 609 F.2d 411 (9th Cir. 1979), cert. denied, 48 U.S.L.W. 3694 (U.S. April 28, 1980) (No. 79-1383) (striking demand for jury trial because of complexity of case; 18 cases were consolidated for trial, five classes were certified, 20 individual defendants and 80 corporate or partnership defendants were involved, and many of the defendants filed cross-claims).

18. E.g., In re Boise Cascade Sec. Litigation, 420 F. Supp. 99, 104 (W.D. Wash. 1976) (concern expressed that only persons with no exposure to business world would be deciding lengthy commercial cases).

Chief Justice Burger has recognized this problem:

It borders on cruelty to draft people to sit for long periods trying to cope with issues largely beyond their grasp .... Even Jefferson would be appalled at the prospect of a dozen of his yeomen and artisans trying to cope with some of today's complex litigation in a trial lasting many weeks or months.

Nat'l L.J., supra note 2, at 21, col. 1-2 (quoting address by Chief Justice Warren Burger to the Conference of State Chief Justices (Aug. 7, 1979)).

19. See, e.g., Zenith Radio Corp. v. Matsushita Elec. Indus. Co., 478 F. Supp. 889, 934 (E.D. Pa. 1979) (jury critics overlook fact that alternative to lay jury is lay judge); Note, The Securities Exchange Act and the Rule of Exclusive Federal Jurisdiction, 89 YALE L.J. 95, $104 \mathrm{n.39}$ (1979) (assuming choice is between jury trial and bench trial in complicated securities cases).

20. See Zenith Radio Corp. v. Matsushita Elec. Indus. Co., 478 F. Supp. 889, 934-35 (E.D. Pa. 1979); Higginbotham, supra note 7, at 53.

21. See, e.g., Zenith Radio Corp. v. Matsushita Elec. Indus. Co., 478 F. Supp. 889, 935 (E.D. Pa. 1979).

22. See Higginbotham, supra note 7 , at 54 (process of distilling complex material into comprehensible form cperates less effectively in bench trials than in jury trials because rules of evidence only loosely followed in bench trials). 
atmosphere of a bench trial. ${ }^{23}$ Furthermore, juries have been praised for bringing elements to their decisions that judges alone cannot provide. A judge can write reasoned opinions on the basis of knowledge and experience, but only a jury can make so-called "black-box decisions"; 24 when the equities of the case do not lend themselves to reasoned articulation, a jury can render judgment without explanation, avoiding the need for a formal judicial opinion that might seem unconvincing or arbitrary. Moreover, only a jury can "insure that the decisions will reflect contemporary community values in courts otherwise dominated by judges with life tenure." ${ }^{25}$ Finally, the Seventh Amendment may limit the ability to do away with the jury in many complicated suits.

Trial of complex cases by a special jury is a desirable alternative to trial by a judge alone or to trial by an ordinary jury. A jury composed of particularly qualified individuals could understand sophisticated concepts that might be beyond the abilities of either a judge or a traditional jury. Jury confusion would be less of a problem than it is with jurors who are unfamiliar with the technical, financial, and legal issues involved in much of today's complicated litigation..$^{26}$ There also would be less likelihood of an irrational verdict because the special jurors would be able to make a reasoned decision based on their understanding of the facts and the law.

The presence of a special jury would preserve the advantages of a traditional jury trial over trial by a judge alone. The "fierce discipline" of a jury trial ${ }^{27}$ still would force attorneys to streamline their cases and to present them convincingly. In addition, the jury would be present to provide the "commonsense judgment of the community" and to protect the parties from "the professional or perhaps overconditioned or biased response of a judge." ${ }^{28}$ The original role of the jury "as a protective

23. Id. (in bench trials, counsel drop "evidentiary antennae," lose sensitivity to questions of relevance, and fail to marshal proof; jury trial imposes "a fierce discipline on the advocates").

24. See Zenith Radio Corp. v. Matsushita Elec. Indus. Co., 478 F. Supp. 889, 941 (E.D. Pa. 1979) (quoting Holmes, Law in Science and Science in Law, 12 HArv. L. REv. 443,457 (1899)).

25. Zenith Radio Corp. v. Matsushita Elec. Indus. Co., 478 F. Supp. 889, 941 (E.D. Pa. 1979); see Higginbotham, supra note 7, at 58.

26. See, e.g., In re U.S. Financial Sec. Litigation, 75 F.R.D. 702, 712-13 (S.D. Cal. 1977), rev'd, 609 F.2d 411 (9th Cir. 1979), cert. denied, 48 U.S.L.W. 3694 (U.S. April 28, 1980) (No. 79-1383) (before striking jury demand because case was too complex, court enumerated issues with which trier of fact would have to be familiar in order to render verdict).

27. Higginbotham, supra note 7, at 53-54.

28. Taylor v. Louisiana, 419 U.S. 522,530 (1975). 
shield between the litigants and the danger of an arbitrary decision by the sovereign" 29 would thus remain intact.

\section{Special Juries and the Constitution}

Although the special jury may be a desirable alternative to either a bench trial or a traditional jury trial, it cannot be employed unless it satisfies the Constitution's requirements for trial by jury. The Seventh Amendment and the due process clause of the Fifth Amendment establish the constitutional standards for civil jury trials. The special jury must be shown to meet these standards while providing a practical solution to the problems of complex civil litigation.

\section{A. The Seventh Amendment and the Historical Test}

The Seventh Amendment "preserved" the right of trial by jury in suits at common law when the amount in controversy exceeds twenty dollars. ${ }^{30}$ The absence from the body of the Constitution of any provision for jury trials in civil cases was a primary source of controversy during the ratification debates of $1787-1788,{ }^{31}$ yet there remains almost no direct evidence of the intent of the framers of the Amendment itself. ${ }^{32}$ Lacking any documentary assistance in construing the Seventh Amendment, courts generally have decided whether a party has a right to a jury trial in a given case by reference to English practice in 1791, the date of the adoption of the Bill of Rights. ${ }^{33}$ On the basis of his-

29. ILC Peripherals Leasing Corp. v. International Business Machs. Corp., 458 F. Supp. 423,448 (N.D. Cal. 1978).

30. The Seventh Amendment states: "In Suits at common law, where the value in controversy shall exceed twenty dollars, the right of trial by jury shall be preserved. ..." U.S. Const. amend. VII.

31. Wolfram, The Constitutional History of the Seventh Amendment, 57 MinN. L. REv. 639, 668-69 (1973). The delegates to the Federal Convention of 1787 discussed a jury trial guarantee for civil cases only briefly and only during the last days of the convention. In the end, they chose not to include in the Constitution any provision for the right to a jury trial in civil cases. $I d$. at 656-66. That omission-indeed the absence of any bill of rights-became one of the major weapons in the antifederalist arsenal during the ratification debates of $1787-1788$. Id. at $667-725$ (state-by-state account of ratification debates concerning omission of jury trial guarantee from Constitution). The issue did not prove sufficient to block ratification, but a guarantee of a jury trial in civil cases was included in the Bill of Rights with little recorded discussion. Id. at 725-30. See generally R. Rutland, The Birth of the Bill of Rights, 1776-1791 (1955).

32. See Henderson, The Background of the Seventh Amendment, 80 Harv. L. REv. 289, 291 (1966).

33. See, e.g., Dimick v. Schiedt, 293 U.S. 474 (1935). The historical test for applying the Seventh Amendment was first enunciated in 1812 by Justice Story in United States v. Wonson, 28 F. Cas. 745 (No. 16,750) (C.C.D. Mass. 1812):

Beyond all question, the common law here alluded to [in the Seventh Amendment] is not the common law of any individual state, (for it probably differs in all), but it 
torical investigation, the courts determine whether the case would have gone to a jury in eighteenth-century England. If so, the Amendment is held to grant a right to a jury trial. Should the suit be of a type unknown in the eighteenth century-for example, an antitrust matter-reference is made to the closest common law analogue as the basis for the decision. ${ }^{34}$

Once it has been determined that a right to a jury trial exists in a given case, there is a certain amount of freedom in giving procedural form to the constitutional right. ${ }^{35}$ Courts frequently have held that the aim of the Seventh Amendment was to preserve the substance of the jury trial right rather than the exact incidents and details of eighteenthcentury procedure ${ }^{36}$ As Justice Brandeis stated, "New devices may be used to adapt the ancient institution to present needs and to make of it an efficient instrument in the administration of justice. Indeed, such changes are essential to the preservation of the right." 37 Reasonable modifications of the jury trial right have been allowed so long as they do not conflict with the fundamental meaning of the Amendment. ${ }^{38}$ In recent years, historical interpretation of the right to a civil jury under the Seventh Amendment has been attacked on a number of fronts, ${ }^{30}$ and the Supreme Court has provided hints that its loyalty to

is the common law of England, the grand reservoir of all our jurisprudence. It cannot be necessary for me to expound the grounds of this opinion, because they must be obvious to every person acquainted with the history of the law.

Id. at 750. No further authority was given for this reference to English practice; the test as stated in Wonson remains virtually unchallenged. As one commentator observed, "perhaps later judges have hesitated to appear to be the kind of intractable person that would require Mr. Justice Story to elaborate on the obvious." Wolfram, supra note 31, at 641 .

Although courts did not begin using the English practice of 1791 as the standard until after IFonson, that facet of the historical test is now well-entrenched. See Dimick v. Schiedt, 293 U.S. 474, 476 (1935). The explanation for not having focused earlier on the practice of 1791 may simply be the requirements of an evolving common law. The time frame may have been irrelevant in earlier cases because the practices in dispute were substantially the same as they had been in the eighteenth century. Only when new procedures had emerged and old ones had undergone major changes was reference to the practice of a particular date necessary. Wolfram, supra note 31, at 642 .

34. See, e.5., Harris \& Liberman, supra note 9, at 611-12 \& n.5 (discussing common law analogues to present antitrust laws).

35. See, e.g., Colgrove v. Battin, 413 U.S. 149, 155-60 (1973) (intention of framers was to preserve right to jury trial rather than mere formal incidents of trial by jury).

36. E.g., Galloway v. United States, 319 U.S. 372, 390, 392 (1943); Baltimore \& Carolina Line, Inc. v. Redman, 295 U.S. 654, 657 (1935).

37. Ex parte Peterson, 253 U.S. 300, 309-10 (1920) (footnote omitted).

38. See Henderson, supra note 32, at 336-37; Note, Mutuality of Estoppel and the Seventh Amendment: The Effect of Parklane Hosiery, 64 CoRnell L. REv. 1002, 1022 (1979).

39. Criticism of the historical test has taken many forms. Some critics have argued that adherence to the test binds courts to antiquated eighteenth-century procedures, e.g., Comment, supra note 4 , at 787 , that do not always yield quick or correct results, e.g., Note, supra note 38 , at 1023 . Other observers have attacked the use of a historical test not because of any inherent defects, but because of mistakes in its application. They point 
the historical test is giving way. ${ }^{40}$ Nonetheless, historical analysis remains the norm for examining jury trial questions. ${ }^{41}$ Any proposed change in the use of civil juries thus must be shown to comport with the practice of English courts in 1791.

out that assumptions about eighteenth-century English practices are often questionable, see, e.g., Chesnin \& Hazard, Chancery Procedure and the Seventh Amendment: Jury Trial of Issues in Equity Cases Before 1791, 83 YALE L.J. 999, 1018, 1020 (1974) (contrary to usual assumption, evidence indicates use of jury trial to decide issues of fact in English Court of Chancery in eighteenth century), while the historical inquiry that occurs frequently leads to erroneous or inconclusive results, see, e.g., Note, supra note 38, at 1023 .

In place of a strict historical test, various of these critics have suggested that the Seventh Amendment be interpreted flexibly, Henderson, supra note 32, at 336-37, or with a "dynamic' reading," Wolfram, supra note 31, at 745 . A more cynical opponent of the civil jury has recommended that the historical test be applied rigorously in order to restrict the use of a jury to precisely those actions in which such a right existed in eighteenth-century England. Redish, supra note 4, at 514-17. The only proposal to have received a measure of judicial approval would read the Fifth Amendment right to due process of law as limiting the Seventh Amendment right to a jury trial. Comment, supra note 4, at 798-99; see In re Boise Cascade Sec. Litigation, 420 F. Supp. 99, 104 (W.D. Wash. 1976) (if jury not impartial and capable finder of fact, fairness guaranteed to litigants by Fifth and Fourteenth Amendments may be denied).

40. See, e.g., Ross v. Bernhard, 396 U.S. 531 (1970) (despite historical tradition to contrary, Seventh Amendment right to jury trial extends to stockholder's derivative suit with respect to issues upon which corporation suing in its own right would have been entitled to jury trial). The Ross Court stated that among the factors to be considered in determining whether there is a right to a jury trial under the Seventh Amendment are "the practical abilities and limitations of juries." $I d$. at 538 n.10. This unsupported footnote is at the center of the debate over the existence of a right to a jury trial in a complex civil case.

Those who oppose the use of juries in complex cases argue that the Ross footnote is of constitutional dimension, creating a complexity exception to the Seventh Amendment right to a jury trial. See, e.g., In re U.S. Financial Sec. Litigation, 75 F.R.D. 702, 710-11 S.D. Cal. 1977), rev'd, 609 F.2d 411 (9th Cir. 1979), cert. denied, 48 U.S.L.W. 3694 (U.S. April 28, 1980) (No. 79-1383); In re Boise Cascade Sec. Litigation, 420 F. Supp. 99, 105 (W.D. Wash. 1976). Proponents of the jury point to the long tradition of the historical test and contend that the Supreme Court would not break with such a tradition in a footnote as cursory as that in Ross. They refuse to regard the Ross footnote as anything but the most general guide for applying the Seventh Amendment and certainly not a constitutional ruling. See, e.g., In re U.S. Financial Sec. Litigation, 609 F.2d 411, 425 (9th Cir. 1979), cert. denied, 48 U.S.L.W. 3694 (U.S. April 28, 1980) (No. 79-1383); Zenith Radio Corp. v. Matsushita Elec. Indus. Co., 478 F. Supp. 389, 926-27 (E.D. Pa. 1979).

The Supreme Court has made no effort to expand upon its elusive statement in Ross. In the absence of further judicial explanation, even critics of the historical interpretation have been forced to admit to its continued vitality. See, e.g., Shapiro \& Coquillette, The Fetish of Jury Trial in Civil Cases, 85 HAkv. L. REv. 442, 449 (1971). This Note bypasses the Ross controversy over the right to a jury trial in a complex case by arguing that, regardless of the outcome of the current debate, the special jury preserves the best features of both traditional jury trial and bench trial and is, therefore, a constitutional and desirable solution to the problems presented by the complex case.

41. See, e.g., Colgrove v. Battin, 413 U.S. 149 (1973) (historical inquiry made before reaching decision that six-person jury satisfies Seventh Amendment right to jury in civil cases); In re U.S. Financial Sec. Litigation, 609 F.2d 411 (9th Cir. 1979), cert. denied, 48 U.S.L.W. 3694 (U.S. April 28, 1980) (No. 79-1383) (reaffirming validity of historical test and denying complexity exception to Seventh Amendment); Zenith Radio Corp. v. Matsushita Elec. Indus. Co., 478 F. Supp. 338 (E.D. Pa. 1979) (denying motion to strike jury demand in complex case after extensive historical discussion). 
Special juries are in fact part of a long historical tradition in England. Juries of particularly qualified persons have been in use since the middle ages to decide cases that might be outside the experience of ordinary jurors. ${ }^{42}$ In fourteenth-century London, juries of fishmongers and cooks sat in judgment on persons accused of selling bad food..$^{43}$ Although these special or merchant juries continued to be employed in commercial settings throughout the next several centuries, ${ }^{4 t}$ their use was irregular and unsystematic until the eighteenth century. ${ }^{45}$

In 1724, however, a case arose addressing the right to a special jury in a trial at nisi prius. ${ }^{40}$ Whether prompted by that case or for other reasons, Parliament in 1730 passed An Act for the Better Regulation of Juries. ${ }^{47}$ The Act granted either party a right to a special jury in trials at bar or at the assizes ${ }^{48}$ and also detailed the procedures to be

42. See Thayer, The Jury and Its Development (pt. 2), 5 HARv. L. Rev. 295, 300 (1892). The special jury as used in England was of two basic types. The first type was composed of persons possessing expertise in some nonlegal field to act as informed judges of the facts in matters requiring their special knowledge. See W. CoRnish, The JuRY 31-32 (1968). It is this first type of special or merchant jury that is of interest for the purposes of this Note. The second type of special jury simply employed persons of higher social or economic status; no special knowledge or background was required. Id. This latter form of the special jury was used in criminal prosecutions as well as in civil cases, a practice that was denounced during the seditious libel trials of the late eighteenth century. Id. at 32. But see THE LeTters of Junius 19 (J. Cannon ed. 1978) (special jury proposed as alternative fact-finder if ordinary jury thought incapable of recognizing seditious libel). It seems to have been the second type of special jury that provoked Jeremy Bentham's vitriolic attack on the use of special juries. J. Bentham, The Elements of the ART of Packing as Applied to Special Juries (London 1821).

43. See Thayer, supra note 42 , at 300 .

44. See, e.g., 2 J. Lilly, The Practical Register 122 (London 1719), 154 (2d ed. London 1745). Lilly's Practical Register was a brief compendium of the case law similar to present-day digests. That the merchant jury was mentioned in both the 1719 and the 1745 editions indicates that special or merchant juries had been a feature of the English legal landscape since at least the beginning of the eighteenth century. Cf. Pickering v. Barkley, Styles 132, 82 Eng. Rep. 587 (K.B. 1649) (merchant jury called in "to satisfie the Court" regarding matter of mercantile usage, but unclear whether merchant jury actually rendered verdict).

45. See C. Fifoot, Lond MANSField 104 (1936).

46. Rex v. Burridge, 8 Mod. 245, 88 Eng. Rep. I75 (K.B. 1724). The question in Burridge was whether a special jury could be ordered without the consent of both parties in a trial at nisi prius, that is, a trial held before justices riding circuit. The master searched for precedents and found several such cases, though all were more than 30 years old. Since that time, motions for a special jury at nisi prius had all been denied. The justices decided that a special jury might be granted to try causes at bar without the consent of the parties, but not in trials at nisi prius unless some good cause could be shown. Id. at 248,88 Eng. Rep. at 177.

47. 3 Geo. 2 , c. 25 (1730).

48. Id. \$ 15; see $3 \mathrm{~W}$. Blackstone, Commentaries *358 (interpreting the statute to that effect). Trial at bar refers to trial before the full court sitting at Westminster Hall. See T. Plucknetr, A Concise History of the Common Law 165-67 (5th ed. 1956). This is to be distinguished from trial at nisi prius or the assizes, both of which usually were held before justices riding circuit. Although commissions of assize and those of nisi prius 
used in selecting and compensating such juries. ${ }^{49}$ The statute was made perpetual in $1733^{50}$ and was further amended in $1751 .{ }^{51}$ After 1730 , the use of the special jury gradually became more frequent. ${ }^{52}$

Under Lord Mansfield, Chief Justice of the King's Bench from 1756 to $1788,{ }^{53}$ special juries were "converted [from] an occasional into a regular institution." 54 Prior to Lord Mansfield's tenure, the common law was without a set of well-defined principles by which to resolve commercial disputes. ${ }^{55}$ Mansfield began filling this void by allowing special juries of London merchants to decide commercial cases according to the common practice and experience of their profession. ${ }^{50}$ The Chief Justice would then use the jury's findings to state broad legal principles. ${ }^{57}$ Mansfield and his fellow justices employed special juries

had different origins and were for different purposes, they had been combined in the middle ages into a system known by the eighteenth century as the assizes. See J. BAKER, AN INTRODUction to ENGLISH Legal. History 19-20 (2d ed. 1979).

49. An Act for the Better Regulation of Juries, 3 Geo. 2, c. 25, $\$ \$ 16-18$ (1730).

50. 6 Geo. 2, c. $37, \S 1$ (1733). In the eighteenth century, Parliament regularly passed laws that were to expire after three years. At the end of that time the statute could be allowed to expire automatically, it could be renewed for another limited period of time, or it could be made perpetual. To make an act perpetual meant only that it would be in effect until repealed by a subsequent act of Parliament. See, e.g., E. Thompson, Whics AND HUNTERS 206 (1975).

51. An Act for the Better Regulation of Trials by Jury, 24 Geo. 2, c. 18, $\S \S 1-2$ (1751).

52. See, e.g., Richardson v. Bradshaw, 1 Atk. 128, 26 Eng. Rep. 84 (K.B. 1752) (on direction from Chancery, two issues regarding mercantile usage under bankruptcy statutes tried by special jury); Wilks v. Eames, Andrews 51, 95 Eng. Rep. 293 (K.B. 1737) (suit on insurance policy tried by special jury at nisi prius in London).

53. William Murray, Lord Mansfield, dominated the Court of King's Bench during his term as Chief Justice and generally is credited with having transformed mercantile law from a chaotic conglomeration of customs into a systematic body of doctrine. See C. Fifoot, supra note 45 (legal biography); Rigg, William Murray, first Earl of Mansfield, 39 Dictionary of National BIography 409-15 (1894) (general biographical information).

54. C. Frfoot, supra note 45 , at 105 .

55. See W. CoRNish, supra note 42 , at $31-32$.

56. See, e.g., Lewis v. Rucker, 2 Burr. 1167, 97 Eng. Rep. 769 (K.B. 1761) (measure of damages under policy insuring ship's cargo decided by jury of merchants). In the course of his opinion in Lewis, Lord Mansfield stated the case for the use of special merchant juries:

The special Jury, (amongst whom there were many knowing and considerable Merchants,) found the Defendant's Rule of Estimation to be right, and gave their Verdict for him. They understood the Question very well, and knew more of the Subject of it than any Body else present; and formed their Judgment from their own Notions and Experience, without much Assistance from any thing that passed.

Id. at 1168, 97 Eng. Rep. at 770 .

It appears that merchant juries sometimes acted as nothing more than advisory juries or expert witnesses. See, e.g., Hankey v. Jones, 2 Cowper 745, 98 Eng. Rep. 1339 (K.B. 1778). The cases and the statute make it clear, however, that merchant juries also were employed to make a final determination of the general issue. See, e.g., notes 59-64 infra (citing cases employing merchant juries); 3 Geo. 2, c. 25 (1730) (regulating use of special juries).

57. See C. FIFoor, supra note 45, at 108-09. By formulating legal principles out of the special jury's findings, Lord Mansfield was codifying the diverse practices of merchants 
in a wide variety of commercial situations, ${ }^{58}$ including cases concerning negotiable instruments, ${ }^{59}$ marine insurance policies, ${ }^{60}$ contracts for the sale of goods, ${ }^{01}$ and the bankruptcy statutes. ${ }^{62}$ The special jury was not, however, permitted to dictate to the court. If the jury's decision was unreasonable or contrary to previously decided cases, the court would step in and settle the matter as one of law. ${ }^{63}$

The institution of the merchant jury did not die with Lord Mansfield. Lord Ellenborough of the King's Bench carried Mansfield's methods for employing the special jury into the nineteenth century ${ }^{6: t}$ and statutes mentioning the special jury appeared in $1825^{65}$ and again

into a consistent body of commercial law. $I d$. Trial judges are no longer expected to fill such an expansive role as codifiers, nor would it be required of them under this Note's proposal for the use of special juries. See pp. 1172-76 infra.

58. Although Lord Mansfield took the lead in the use of merchant jurors to decide cases that were outside the experience of ordinary jurors, he does not seem to have been alone in his use of the device. See, e.g., Rickford v. Ridge, 2 Campb. 537, 170 Eng. Rep. 1243 (K.B. 1810) (Ellenborough, C.J., presiding at trial); Tindal v. Brown, 1 T.R. 167, 99 Eng. Rep. 1033 (K.B. 1786) (Buller, J., presiding at trial); Richardson v. Bradshaw, 1 Atk. 128, 26 Eng. Rep. 84 (K.B. 1752) (Lee, C.J., presiding at trial). But see Devlin, Jury Trial of Complex Cases: English Practice at the Time of the Seventh Amendment, 80 Colum. L. REv. 43, 83 (1980) (no indication that " 'trained corps of jurors" " was ever employed outside of Lord Mansfield's domain).

59. E.g., Tindal v. Brown, I T.R. 167, 99 Eng. Rep. 1033 (K.B. 1786); Grant v. Vaughan, 3 Burr. 1516, 97 Eng. Rep. 957 (K.B. 1764).

60. E.g., Camden v. Cowley, I Black.W. 417, 96 Eng. Rep. 237 (K.B. 1763); Lewis v. Rucker, 2 Burr. 1167, 97 Eng. Rep. 769 (K.B. 1761).

61. E.g., Hodgson v. Davies, 2 Campb. 530, 170 Eng. Rep. 1241 (K.B. 1810).

62. E.g., Richardson v. Bradshaw, I Atk. 128, 26 Eng. Rep. 84 (K.B. 1752).

63. See, e.g., Rickford v. Ridge, 2 Campb. 537, 170 Eng. Rep. 1243 (K.B. 1810). In Rickford the issue was the time within which a check or bill had to be presented for payment. A member of the special jury observed that the practice of merchants varied according to the different commercial customs obtaining east and west of St. Paul's in London. Lord Ellenborough held that the question was one of the payee's reasonable diligence; whatever the practices were in various parts of London, the legal rule must be one of commercial convenience. Id. at 538-40, 170 Eng. Rep. at 1244-45. Justice Buller stated a similar view in Appleton v. Sweetapple, 3 Doug. 137, 99 Eng. Rep. 579 (K.B. 1782):

In a question of law, however unpleasant it may be to us, we must not yield to the decision of a jury. I do not doubt that a special jury in London will, if desired, find a special verdict. The usage is to be considered, but such usage must be reasonable, and it is for the Court to say whether it is good or bad.

Id. at 140, 99 Eng. Rep. at 580 .

It has been recognized that some judicial control of juries was practiced in eighteenthcentury England. See Henderson, supra note 32, at 299-320. Despite these methods of control, however, special juries retained the power to determine the general issue. See note 56 supra. Similarly, modern mechanisms for jury control-such as judgments n.o.v. and directed verdicts-could be employed today without sacrificing the benefits of trying complex cases before special juries.

64. See, e.g., Rickford v. Ridge, 2 Campb. 537, 170 Eng. Rep. 1243 (K.B. 1810) (special jury used in case concerning negotiable instruments); Hodgson v. Davies, 2 Campb. 530 , 170 Eng. Rep. 1241 (K.B. 1810) (special jury employed in suit on contract for sale of goods).

65. 6 Geo. 4 , c. $50, \S \S 30-36(1825)$. 
in $1852 .{ }^{66}$ All of the evidence indicates that, in 1791, the use of special juries in cases outside the experience of ordinary jurors was an established part of English procedure. ${ }^{67}$ Thus the use of special juries in modern complex litigation would satisfy the historical requirements of the Seventh Amendment.

\section{B. The Cross Section of the Community Standard and Due Process of Law}

The Constitution requires more of the special jury than that it meet the historical test of the Seventh Amendment. A litigant is also constitutionally entitled to a jury drawn from a cross section of the com-

66. Common Law Procedure Act, $1852,15 \& 16$ Vict., c. 76, $\$ \S 108-113$. The special jury survived in England in one form or another well into this century. Special juries were abolished by statute in 1949. Jurics Act, 1949, 12 \& 13 Geo. 6, c. $27, \S 18$. Although an exception was made to preserve the special juries from the City of London in commercial cases in the King's Bench Division, id. $\$ 19$, no special jury has been used since 1950 . W. CoRnish, supra note 42, at 33. In 1971 Parliament abolished the special jury altogether. Courts Act, 1971 , c. $23, \S 40$. It must be borne in mind that the special jury has had company in its neglect; the civil jury in general has all but disappeared from English courts. See W. CoRNish, supra note 42 , at 33 .

67. See 3 M. Bacon, A New Abridgment of the Law 250 (5th ed. London 1786) (6th ed. London 1793), 745 (1st American ed. from 6th London ed. Philadelphia 1813) (mentioning use of special juries).

Although colonial American lawyers were aware of the use of special juries in commercial matters, evidence indicates that the practice was never as extensive here as in England. See M. Horwitz, The Transformation of American LAw 155-59 (1977). Both New York and South Carolina had statutes allowing the use of special juries in mercantile disputes. Id. at 155, 158. The statutes were passed during the colonial period but continued in force after independence had been won. $I d$. at 155, 158. Although the statutes remained on the books, special juries seem to have been used only rarely in either state after the first decade of the nineteenth century. Id. at 157-59. The reasons for the disappearance are unclear. Morton Horwitz suggests that a general pattern of judicial hostility to competing sources of law was one factor. Id. at 155. Perhaps another was the fragmentation of the community of interest among merchants. See id. at 159. Whatever the reasons, it is certain that the use of particularly qualified special jurors to determine questions of fact within their area of expertise has not appeared in America since the early nineteenth century.

Special juries of other types were in occasional use in various parts of the United States well into the twentieth century. There seems to be no pattern to these manifestations of the special jury either in selection procedures or in the cases to be tried. See generally Baker, supra note 9 (explaining and defending New York's well-developed special jury system); Thatcher, supra note 9 , at $241-42$ (discussing Minnesota's nineteenth-century experiment with special juries). New York appears to be the only state to have used special juries extensively in this century. Such juries were employed in criminal prosecutions for corruption, in large will contests, in suits involving stocks or bonds, and in other complicated litigation. See Thatcher, supra note 9, at 252-54. Although the New York special jury system was held to be constitutionaJ, Fay v. New York, 332 U.S. 261 (1947), the device seems to have fallen into disuse and was eliminated in 1965, Act of July 15 , 1965 , ch. $778, \S 3,1965$ N.Y. Laws 1853 . Because the historical test requires reference to eighteenth-century English practice, the Amcrican experience of special juries is irrelevant except insofar as it reflects a certain amount of constitutional acceptance. Cf. Fay v. New York, 332 U.S. 261 (1947) (affirming constitutionality of New York's special jury system). 
munity ${ }^{88}$ and to one that comports with the twin due process requirements of impartiality and rationality ${ }^{69}$ Under the mandate of crosssectionality, Congress and the courts require that juries fairly represent the communities from which they are drawn; ${ }^{70}$ potential jurors must be selected at random from a cross section of the population ${ }^{71}$ in order not to violate the constitutional standards of due process and equal protection. ${ }^{22}$ Trial by other than a group chosen from a cross section of the community has been said to weaken the institution of the jury trial, ${ }^{73}$ to reduce public participation in the judicial process, ${ }^{74}$ and to endanger a litigant's rights. ${ }^{75}$ Furthermore, the values of the community may not be represented if the jury is drawn from less than a

68. See Thiel v. Southern Pac. Co., 328 U.S. 217, 220 (1946).

69. See Peters v. Kiff, 407 U.S. 493,501 (1972) (plurality opinion of Marshall, J.); In re Boise Cascade Sec. Litigation, 420 F. Supp. 99, 104 (W.D. Wash. 1976).

70. See, e.g., Glasser v. United States, 315 U.S. 60, 86 (1942) (prohibiting exclusion from jury service of all women who had not attended jury preparation classes conducted by prosecution); 28 U.S.C. $\$ 1861$ (1976) (requiring that grand and petit juries be selected at random from fair cross section of community).

71. See, e.g., Taylor v. Louisiana, 419 U.S. 522, 528 (1975) (male kidnapping defendant denied right to trial by impartial jury because no women included on jury venire unless they specifically requested to be subject to jury service); Thiel v. Southern Pac. Co., 328 U.S. 217, 220 (1946) (constitutionally unjustified to exclude daily wage-earners from jury service in civil personal injury suit). Thiel is the only case in which the Court has applied the cross-section requirement to civil juries. The opinion makes clear that the cross-section standard applies to civil and criminal cases with equal strength. Id. at 220; cf. 28 U.S.C. $\$ 1861$ (1976) (no exception to cross-section requirement stated for civil jury').

There is a possibility of confusion over whether the cross-section requirement applies to the jury itself or only to the selection of jury venires. The language of some opinions might create the impression that a cross section of the community must be represented on each jury. See, e.g., Goins v. Allgood, 391 F.2d 692, 699 (5th Cir. 1968) (desire for competent jurors must not lead to selections that do not comport with concept of jury as cross section of community). This would cause difficult practical problems and would call into question the constitutionality of the peremptory challenge. See Note, Peremptory Challenges and the Meaning of Jury Representation, 89 YALE L.J. 1177 (1980) (opposing application of Taylor to limit peremptory challenge); cf. Note, Limiting the Peremptory Challenge: Representation of Groups on Petit Juries, 86 YaLE L.J. 1715 (1977) (favoring application of Taylor to limit peremptory challenges that cause "unrepresentative" juries). The most recent Supreme Court cases interpreting cross-sectionality seem to apply the standard to jury venires alone. See Duren v. Missouri, 439 U.S. 357, 363.64 (1979); Taylor v. Louisiana, 419 U.S. 522, 538 (1975). It is clear that a jury need not be a mirror image of the community. Id.

72. E.g., Cobbs v. Robinson, 528 F.2d 1331, 1334 (2d Cir.), cert. denied, 424 U.S. 947 (1975); Brooks v. Beto, 366 F.2d 1, 11 (5th Cir. 1966), cert. denied, 386 U.S. 975 (1967).

73. See Glasser v. United States, 315 U.S. 60, 86 (1942).

74. See, e.g., Taylor v. Louisiana, 419 U.S. 522, 529-30 (1975) (legislative history of federal Jury Selection and Service Act of 1968 demonstrates congressional recognition that jury "plays a political function in the administration of the law" and that requirement of jury chosen from fair cross section of community is "fundamental to the American system of justice"); Glasser v. United States, 315 U.S. 60, 85 (1942) (notions of proper jury role have developed in harmony with "basic concepts of a democratic society and a representative government").

75. See Peters v. Kiff, 407 U.S. 493, 503 (1972) (plurality opinion of Marshall, J.) (white defendant denied due process because blacks excluded from grand and petit juries). 
fair cross section. ${ }^{76}$ Broad community participation in the administration of justice must be maintained, for it is critical to public confidence in the judicial system. ${ }^{77}$

Despite the apparent force of the cross-section requirement, it is not the potent engine against the use of special juries that might be supposed. Not only are the cases setting forth the cross section of the community standard distinguishable, ${ }^{78}$ the standard itself has its limits. The state has been found to have a legitimate interest in excluding from jury service persons who are not equal to the tasks that will be required of them. ${ }^{79}$ The cross-section requirement thus allows reasonable classifications of persons that are related to the individual's ability to perform the duties of a juror efficiently and intelligently. ${ }^{80}$ To this end, the federal Jury Selection and Service Act of $1968^{81}$ disqualifies certain groups from jury service: anyone who is not a United States citizen; anyone unable to read, write, speak, or understand English; anyone whose mental or physical infirmities render satisfactory jury service impossible; and anyone charged with or convicted of a felony. ${ }^{82}$ These

76. Cf. Zenith Radio Corp. v. Matsushita Elec. Indus. Co., 478 F. Supp. 889, 941 (E.D. Pa. 1979) (only jury can ensure that verdicts will reflect contemporary community values in courts dominated by tenured judges).

77. Taylor v. Louisiana, 419 U.S. 522, 530 (1975).

78. The cases requiring that juries represent a cross section of the community comprise a narrow range of situations that are distinguishable from those encountered in complex civil litigation. All of the cross-sectionality cases addressed efforts to identify and exclude from the jury members of a particular group for reasons unrelated to their ability to perform the functions of jurors. See, e.g., Hernandez v. Texas, 347 U.S. 475, 48081 (1954) (persons of Mexican ancestry); Thiel v. Southern Pacific Co., 328 U.S. 217, 221 (1946) (persons earning a daily wage). The particular circumstances of many of the cases suggest a concern on the part of the courts that the jury selection process was being used to persecute minorities and to exclude them from the institutions of government. See, e.g., Peters v. Kiff, 407 U.S. 493 (1972) (plurality opinion of Marshall, J.); Carter v. Jury Comm'n of Greene County, 396 U.S. 320 (1970). In addition, a majority of the cases were criminal trials in which those excluded from the jury were likely to have been morc receptive to the defendant's point of view. See, e.g., Hernandez v. Texas, 347 U.S. 475 (1954) (persons of Mexican ancestry excluded from Mexican-American defendant's jury); Smith v. Texas, 311 U.S. 128 (1940) (blacks excluded from black defendant's jury). But see Peters v. Kiff, 407 U.S. 493, 500 (1972) (plurality opinion of Marshall, J.) (exclusion of discernible class from jury service injures not only defendants who belong to excluded class, but other defendants as well). Selecting special juries would not require the identification or exclusion of any particular group, nor, under the proposal outlined in this Note, see pp. 1172-76 infra, would the complex cases isolated for trial before a special jury present opportunities for personal prejudice or individual bias to affect the jury's deliberations.

79. Cobbs v. Robinson, 528 F.2d 1331, 1336 (2d Cir.), cert. denied, 424 U.S. 947 (1975).

80. E.g., Carter v. Jury Comm'n of Greene County, 396 U.S. 320, $331-33$ (1970) (ordering county officials to administer permissible qualifications of honesty, intelligence, integrity, good character, and sound judgment in Alabama jury selection system so as not to exclude black citizens from grand and petit juries); Fay v. New York, 332 U.S. 26I, 270-71 (1947) (conviction by New York special jury constitutional).

81. 28 U.S.G. $\$ \S 1861-1875$ (1976).

82. Id. $§ 1865$. 
limits to the cross section of the community standard, all of which are constitutional, ${ }^{83}$ can be seen as an attempt to ensure the selection of jurors better able to understand the issues in a case and to return a verdict based on a reasoned evaluation of the facts. ${ }^{8 t}$ Cross-sectionality requires only that no cognizable group in the community be excluded systematically from jury panels. ${ }^{85}$ Although this does not mean that each jury must contain members of every cognizable group ${ }^{80}$ a jury selection procedure that resulted in any systematic exclusion would violate the Constitution. ${ }^{87}$

The rule that juries must be drawn from a cross section of the community must be considered in harmony with the Fifth Amendment's -due process requirement of a fair trial before a panel of impartial, indifferent jurors. ${ }^{88}$ This "attitude of appropriate indifference" 80 requires the exclusion of any juror who has an interest in the outcome of the trial ${ }^{90}$ or whose opinions of the case have become immutable. ${ }^{01}$

83. See United States v. Test, 550 F.2d 577, 594 (10th Cir. 1976) (statutory disqualification of persons unable to read, write, or understand English excludes no cognizable group from jury service); Eckstein v. Kirby, 452 F. Supp. 1235 (E.D. Ark. 1978) (state statute excluding blind and deaf persons from jury service does not violate Constitution).

84. Cf. Peters v. Kiff, 407 U.S. 493,501 (1973) (plurality opinion of Marshall, J.) (prohibiting use of jurors incapable of rendering impartial verdict based on evidence and law).

85. To establish a violation of $\$ 1861$ of the Jury Selection and Service Act of 1968 , one must show the systematic exclusion of a distinctive or cognizable group in the com. munity. Duren v. Missouri, 439 U.S. 357, 363-64 (1979); United States v. Ross, 468 F.2d 1213, 1217 (9th Cir. 1972), cert. denied, 410 U.S. 989 (1973) (citing United States v. James, 453 F.2d 27, 29 (9th Gir. 1971)). The test for "cognizability" has been held to include, "'(1) the presence of some quality or attribute which 'defines and limits' the group; (2) a cohesiveness of 'attitudes or ideas or experience' which distinguishes the group from the general social milieu; and (3) a 'community of interest' which may not be represented by other segments of society." "Lnited States v. Test, 550 F.2d 577, 591 (10th Cir. 1976) (quoting United States v. Test, 399 F. Supp. 683, 689 (D. Colo. 1975)).

86. Thiel v. Southern Pac. Co., 328 U.S. 217, 220 (1946).

87. See Cobbs v. Robinson, 528 F.2d 1331, 1334 (2d Cir.), cert. denied, 424 U.S. 947 (1975) (equating cross section of community requirement with constitutional standard of due process and equal protection clauses of Fourteenth Amendment).

88. See Irvin v. Dowd, 366 U.S. 717, 722 (1961). The rule that potential jurors be summoned from a cross section of the community may, in part, be a practical way to ensure the selection of impartial juries. In Brooks v. Beto, 366 F.2d 1 (5th Cir. 1966), cert. denied, 386 U.S. 975 (1967), the court stated that "the constitutional imperative [not to pursue a course of conduct that results in racial discrimination in the selection of jurors] is the by-product of experience in finding a practicable means of overcoming the evil consistent with constitutional demands." Id. at 12. The statement seems to imply that the cross section of the community requirement was hit upon by the courts as a rule of thumb for government officials to employ in the selection of jurors. Although there are certainly other values behind the cross-section standard as well, see pp. 1167-68 supra, this link to the due process requirement of impartiality can be of valuable assistance in understanding the true scope of the cross section of the community standard.

89. United States v. Wood, 299 U.S. 123, 145-46 (1936).

90. See Fay v. New York, 332 U.S. 261, 288 (1947) (trial must be held before tribunal not biased by interest in outcome).

91. Irvin v. Dowd, 366 U.S. 717, 722-23 (1961). 
Litigants in civil trials thus are protected from any juror who is "incapable of rendering an impartial verdict, based on the evidence and the law." 92

Even if a juror were impartial, however, he would be incapable of basing his decision on the evidence presented in court if he were not competent to evaluate that evidence. Courts have required that juries be able "to decide the facts in an informed and capable manner"93 and to understand and address rationally the issues of the case. ${ }^{9 t}$ Furthermore, courts have indicated that there is a due process right to a competent and rational finder of fact. ${ }^{95}$ The requirement that jurors be competent to understand the issues of the case is complementary to the statutory elimination from jury service of illiterates, those who speak no English, and those with serious mental or physical infirmities. ${ }^{96}$ The parties are entitled to a jury drawn from "a cross-section of the population suitable in character and intelligence for that civic duty." ${ }^{2}$

92. Peters v. Kiff, 407 U.S. 493, 501 (1972) (plurality opinion of Marshall, J.). Although the Seventh Amendment does not mention impartiality as an essential characteristic of a civil jury, the Court has said, "The American tradition of trial by jury, considered in connection with either criminal or civil proceedings, necessarily contemplates an impartial jury drawn from a cross-section of the community." Thiel v. Southern Pac. Co., 328 U.S. 217,220 (1946).

93. In re Boise Cascade Sec. Litigation, 420 F. Supp. 99, 104 (W.D. Wash. 1976).

94. In re U.S. Financial Sec. Litigation, 75 F.R.D. 702, 711 (S.D. Cal. 1977), rev'd, 609 F.2d 411 (9th Cir. 1979), cert. denied, 48 U.S.L.W. 3694 (U.S. April 28, 1980) (No. 79-1383). Although the Ninth Circuit reversed the district court's holding that therc was no right to a jury trial in this complex case, the opinion specifically witheld judgment regarding "a right to a 'competent' fact-finder." In re U.S. Financial Sec. Litigation, 609 F.2d 4ll, 427 (9th Cir. 1979), cert. denied, 48 U.S.L.W. 3694 (U.S. April 28, 1980) (No. 79-1383).

95. See, e.g., Peters v. Kiff, 407 U.S. 493, 501 (1972) (plurality opinion of Marshall, J.) (due process right to "competent and impartial tribunal"); In re U.S. Financial Sec. Litigation, 609 F.2d 411, 427 (9th Cir. 1979), cert. denied, 48 U.S.L.W. 3694 (U.S. April 28, 1980) (No. 79-1383) ("We assume, without deciding, that there is such a [due process] right to a 'competent' fact-finder."); cf. Kirkham, supra note 1, at 208 (merely to afford opportunity to present evidence and argument in forum unable to comprehend them denies due process and is "a mockery of justice").

Cases in which circumstances were found to have prevented rational decisionmaking provide valuable illustrations of the Supreme Court's position. Trial by an insane juror has been held to constitute a denial of due process, see Peters v. Kiff, 407 U.S. 493,501 (1972) (plurality opinion of Marshall, J.) (citing Jordan v. Massachusetts, 225 U.S. 167, I76 (1912)), as has trial before a jury intimidated by mob violence, see Peters v. Kiff, 407 U.S. 493, 501 (1972) (plurality opinion of Marshall, J.) (citing Moore v. Dempsey, 261 U.S. $86,90-91$ (1923)). If a jury is unable to conduct its deliberations without confusion and uncertainty, the Court has said that the fair trial guaranteed by the due process clause is denied. See Gasoline Prods. Co. v. Champlin Ref. Co., 283 U.S. 494, 500 (1931).

96. See pp. 1168-69 supra.

97. Brown v. Allen, 344 U.S. 443, 474 (1953) (Court will not dictate proper source of jury lists so long as source meets cross-section requirement). The Court has held that litigants are not the only ones to have an interest in constitutional jury selection procedures. Potential jurors themselves have a right not to be excluded from juries by unconstitutional means. Carter v. Jury Comm'n of Greene County, 396 U.S. 320, 329 (1970). This right to nondiscriminatory jury selection does not, however, go beyond the litigants' 
Traditional juries may fall short of satisfying these constitutional requirements of impartiality and rationality when faced with large, complicated cases. Recent decisions have held that ordinary jurors are incapable of deciding complex cases fairly and rationally. ${ }^{98}$ The "commonsense judgment of the community" that the jury is meant to provide $^{99}$ is absent if the jurors cannot comprehend the proceedings. ${ }^{100}$ Rather than protecting litigants from "the exercise of arbitrary power," 101 the jury itself may become the source of arbitrary decisions. ${ }^{102}$

Special juries are a constitutional alternative to ordinary juries in the trial of complex cases. The exclusion from the special jury of persons who are unable to understand the issues does not result in invidious discrimination against a cognizable group ${ }^{103}$ any more than does the permissible statutory disqualification of illiterates or those who do not understand English. ${ }^{104}$ "[There is] no constitutional or statutory right that 'ignorance' be represented in the jury box."10s Selection of special jurors on the basis of their ability to understand

rights. A juror who could not return a rational verdict based on the facts and the law cannot demand that jurors like himself be selected. See Eckstein v. Kirby, 452 F. Supp. 1235, 1241 (E.D. Ark. 1978) (litigant's interest in securing impartial jury superior to individual's interest in serving as juror).

98. See, e.g., ILC Peripherals Leasing Corp. v. International Business Machs. Corp., 458 F. Supp. 423 (N.D. Cal. 1978); Bernstein v. Universal Pictures, 79 F.R.D. 59 (S.D.N.Y. 1978); In re Boise Cascade Sec. Litigation, 420 F. Supp. 99 (W.D. Wash. 1976).

99. See Taylor v. Louisiana, 419 U.S. 522, 530 (1975).

100. See Comment, supra note 4 , at 784 (ordinary jurors may rely on own experience as standard of judgment in criminal, tort, or simple contract actions; such points of reference inapplicable, however, to complicated antitrust and securities violations).

101. Taylor v. Louisiana, 419 U.S. 522, 530 (1975).

102. See ILC Peripherals Leasing Corp. v. International Business Machs. Corp., 458 F. Supp. 423, 448-49 (N.D. Cal. 1978). If the jury is unable to comprehend the facts and the law as presented at trial, the verdict will not reflect a rational resolution of the issues in the case. While one must assume a good-faith effort on the part of jurors to reach a rational decision, they easily could base their verdict on extraneous factors, such as the attitude of the judge or the erudition of the lawyers. The jury thus would cease to be a shield and would become an instrument of arbitrary decisionmaking.

103. Cf., United States v. Henderson, 298 F.2d 522 (7th Cir.), cert. denied, 369 U.S. 878 (1962) (jury selection system tending to eliminate those with less than eighth-grade education is constitutional). Persons excluded from the special jury for their inability to understand the issues in the case would not constitute a cognizable group. Such persons would possess none of the indicia of cognizability as defined in United States v. Test, 550 F.2d 577, 591 (10th Cir. 1976), see note 85 supra (quoting Test standard). Incompetent jurors do not comprise a "community of interest" that would be left unrepresented if they were excluded from the jury. A rural day-laborer and a small-town grocer may neither one comprehend a complicated securities case, but they could hardly be said to share "a cohesiveness of attitudes or ideas or experience" distinguishing them from society at large. Their only common trait would be an inability to understand the complex case and that factor cannot claim constitutional protection.

104. See United States v. Test, 550 F.2d 577, 594 (10th Cir. 1976); 28 U.S.C. § 1865 (1976).

105. United States v. Henderson, 298 F.2d 522, 526 (7th Cir.), cert. denied, 369 U.S. 878 (1962). 
the problems presented in a complex case would exclude only those persons whose lack of comprehension would interfere with rational decisionmaking - a reasonable exclusion similar to those that have been approved by the Court. ${ }^{106}$ Special juries thus could maintain the representational values of the cross-section of the community standard and uphold the due process mandate for jury competence and impartiality. ${ }^{107}$

\section{A Proposal for the Use of Special Juries in Complex Civil Litigation}

This Note proposes that Congress amend the federal Jury Selection and Service Act of $1968^{108}$ to allow the use of special juries in lengthy, complicated civil cases. Any party to a complex suit should be allowed to move for trial by a special jury. ${ }^{109}$ The court would then be required to determine: (a) whether the concepts involved were beyond "the practical abilities and limitations" of an ordinary jury; 110 (b) whether it appeared that the trial would be excessively lengthy, for example, consuming more than fifty trial days; ${ }^{111}$ and (c) whether the use of a special jury would result in unfairness or bias toward any party. If the court determined that the case was indeed complex, that it was likely

106. See pp. 1168-69 supra.

107. The special jury selection procedures proposed in this Note would speak to the problem of obtaining a cross section of competent jurors. The problem of jury impartiality would be solved as it is with traditional juries, by using the challenge for cause. See pp. 1174-75 infra.

108. 28 U.S.C. $\$ \$ 1861-1875$ (1976).

109. Cf. FED. R. Crv. P. 38(b) (procedure for demanding jury trial in federal court).

110. See Ross v. Bernhard, 396 U.S. 531, 538 n.10 (1970); note 40 supra (discussing Ross). Concepts that are beyond a jury's abilities should be only those that require such special knowledge or are so complex that a jury could not be adequately educated about them during the course of the trial.

111. During the 12-month period ending June 30 , 1977, seven civil trials of over 50 trial days in length were completed in the federal courts. [1977] DiREcToR OF THE ADministrative Office of the United States Courts Ann. Rep. Table C-9, at 353. During the 12-month period ending June 30, 1976, nine such trials were completed in the federal courts. [1976] Director of the Administrative Office of the United States Courts ANN. REP. Table C-9, at 334 .

The number of $\mathbf{5 0}$ trial days is somewhat arbitrary and should be regarded as nothing more than a guide in determining whether to use a special jury. Among the cases in which a demand for a jury trial was struck for reasons of complexity, the shortest estimated trial time was four months. See Bernstein v. Universal Pictures, 79 F.R.D. 59 (S.D.N.Y. 1978). In Jones v. Orenstein, 73 F.R.D. 604 (S.D.N.Y. 1977), a motion to strike a jury demand was denied at least in part because the trial was expected to last only two months. Assuming 15 to 20 trial days per month, the Bernstein case would have consumed between 60 and 80 trial days while Jones would have taken 30 to 40 days to try. The figure 50 was chosen because it falls between these estimates. The judge should use his discretion as to what constitutes "protracted" litigation for the purposes of the special jury. 
to be protracted, and that no unfairness would result, the motion for trial by a special jury should be granted. ${ }^{112}$

In deciding whether the use of a special jury would result in any unfairness, the court should consider the nature of the case, the parties involved, and the due process requirements of impartiality and rationality. If the court found that the use of a special jury would be likely to result in a denial of due process to any party, the motion should be denied. ${ }^{113}$ For example, in a derivative suit brought by a small shareholder against the officers of a large corporation, it might be impossible to find special jurors who did not have either a strong pro-corporate or pro-investor bias. If the decision of the case were to turn on these biases, there would be no impartial jury trial. On the other hand, a complex antitrust action by one large corporation against another would seem perfectly suited to the use of a special jury. The opponents would be similar enough that special jurors would not be swayed by inherent biases related to parties. The jurors thus could decide the case on the basis of the evidence and arguments presented in court and not on the basis of the relative positions of the parties.

A different problem for use of the special jury would arise when the bias related not to the parties but to potential jurors' attitudes towards the law. Consider, for example, a government suit to restructure an entire industry. ${ }^{114}$ It might be that anyone qualified for special jury service would oppose massive government interference in the structure of the economy. ${ }^{115}$ Such a jury would be as incapable of deciding the

112. It should be emphasized that motions for a special jury trial are not to be granted haphazardly. The judge should bear in mind that the special jury proposed here is an extraordinary procedure to be used in extraordinary cases. If the matters to be decided are not beyond "the practical abilities and limitations" of ordinary jurors, the special jury should not be employed. Furthermore, if a traditional jury could be educated sufficiently about the issues during the course of the trial, a special jury would be unnecessary. The three conditions of complexity, excessive length, and absence of unfairness must all be met before a motion for a special jury should be granted.

113. Although a motion for trial by a special jury is to be considered within the discretion of the trial court, a ruling on such a motion would be appealable if certified for interlocutory appeal by the district judge under 28 U.S.C. $\$ 1292(\mathrm{~b})$ (1976).

114. See, e.g., In re Kellogg Co., [1970-1973 Transfer Binder] Trade REg. REP. (CCH) I 19,898 (FTC, Dkt. 8883, complaint issued April 26, 1972) (action against ready-to-eat cereal manufacturers). The Kellogg action has been criticized by several commentators. See, e.g., Kiechel, The Soggy Case Against the Cereal Industry, Fortune, April 10, 1978, at 49; Kruse, Deconcentration and Section 5 of the Federal Trade Commission Act, 46 Geo. WASH. L. REv. 200 (1978).

115. American economics and economic education frequently have been attacked for their conservative, free-market bias. See, e.g., Staple, Free-Market Cram Course for Judges, The Nation, Jan. 26, 1980, at 78. Anyone who has acquired the requisite skills to understand certain complex cases thus may have acquired free-market presumptions that render fair and impartial decisions impossible. In addition, depending on the professional and social status of most qualified special jurors, self-interest may unduly bias them for or against certain types of suits. 
case fairly and impartially as would a jury whose members had been unalterably influenced by pretrial publicity. ${ }^{116}$ In such circumstances, the request for a special jury should be denied. ${ }^{117}$

One of the virtues often attributed to trial by jury is that jurors can inject community values into the legal process. ${ }^{118} \mathrm{~A}$ special jury would be useful in situations too complex for the ordinary juror to understand the issues and to apply these community values. When, however, the values of special jurors in a given case diverge sharply from those of the community, the special jury would no longer possess that important representational quality. In such instances as well, the case should be deemed improper for special jury resolution. ${ }^{119}$

Once a court determined that a case was suitable for trial by a special jury, selection of jurors could advance in any of several ways. Two procedures particularly recommend themselves as being practical and efficient while abiding by the requirements of the Seventh Amendment and the due process clause. The first possibility is to use a more elaborate version of the juror qualification form now employed by the federal courts. ${ }^{120}$ Once a motion for a special jury had been granted, the names of as many persons as necessary would be drawn at random from the master jury wheel. ${ }^{121}$ Those whose names were drawn would be sent a juror qualification form to be completed and returned to the court. The form would be designed to identify those persons most likely to understand the issues to be decided in the complicated case at hand. ${ }^{122}$ Persons so identified would be summoned for jury duty ac-

116. See Irvin v. Dowd, 366 U.S. 717 (1961) (pretrial publicity fixing belief of defendant's guilt in minds of potential jurors denied possibility of fair trial).

117. This problem should arise only if there is evidence that all potential special jurors are biased concerning a particular issue. In the case of biased individuals-for example, economists who believe that monopoly is a good thing and will find for the monopolist regardless of the law-the bias should be discovered at voir dire and the individuals excused upon a challenge for cause.

118. See, e.g., pp. 1159, 1167-68 supra; Comment, supra note 4, at 784.

119. If a complex case is inappropriate for a special jury and trial by an ordinary jury or a judge is unacceptable, there may be no practical, constitutional way to decide the suit. Although this would be a disturbing state of affairs from a policy perspective, it would be no different than the situation that now exists. See pp. 1157-59 supra.

120. See 28 U.S.C. $\S 1864$ (a) (1976).

121. Id. $\$ \S 1863(\mathrm{~b})(4), 1864(\mathrm{a})$.

122. What constitutes a person qualified for special jury service would vary with each case. The juror qualification form would have to be designed with the requirements of the specific situation in mind. For example, a questionnaire for a complicated antitrust action might seek to identify persons with a knowledge of economics or, perhaps, with technical training; a form for a securities fraud case may focus more on one's familiarity with the workings of large corporations and corporate finance. Whatever the particular circumstances, anyone who could understand the issues would qualify for the special jury. This proposal is not for special juries composed of experts, but only for jurors drawn from a cross section of the community capable of understanding the facts and the law and of rendering a rational verdict. See p. 1170 supra. 
cording to procedures now obtaining in the federal courts. ${ }^{123}$ The parties could then examine the potential special jurors and exercise their peremptory challenges and challenges for cause. ${ }^{124}$ The advantages to this method would be that a random cross section of competent jurors could be identified and summoned, and that most of the features of the Jury Selection and Service Act would be maintained. The major defect of the plan is that it would require considerable time and effort on the part of the court. It is not inconceivable that hundreds of juror qualification forms would have to be reviewed before competent jurors could be found for whom extended jury service would not constitute an undue hardship. ${ }^{125}$

An alternative selection procedure would not be such a burden on judicial resources. Each side would nominate a representative, the two representatives would choose a third person, and the three of them would assemble a qualified panel of prospective jurors. The court would then examine each of the prospective jurors and the persons who selected them in order to ascertain that no improper criteria such as race or gender were employed in the selection process. Once the court was satisfied that the panel was properly assembled, the jury would be selected employing current procedures. ${ }^{126}$ Under this system,

123. 28 U.S.C. $\S 1866$ (1976).

124. Id. $\$ 1870$. Whatever procedure is used to select a special jury, the criteria for granting challenges for cause or favor will have to be adjusted. At present, a juror who is better prepared by education or experience to understand a complicated case is often the object of a challenge for cause. See p. 1157 supra. If the special jury is to function, judges must not allow challenges to jurors simply because they are better qualified. An alternative formulation might be to excuse a juror only upon a showing that the juror will be unable to decide the case on the basis of the evidence and the law.

125. See 28 U.S.C. $\S 1866$ (c) (1976) (allowing court to excuse persons from jury service upon showing of undue hardship or extreme inconvenience). A major cause of hardship would be financial constraints caused by extended jury service. Because under current law special jurors would receive only a $\$ 30$ per day jury attendance fee, plus travel expenses, $i d . \S 1871(b)$, a juror whose income would be affected by special jury service may suffer severe financial hardship. If service on a special jury would result in economic hardship for a potential juror, the court should consider it an instance of "undue hardship or extreme inconvenience" and excuse the person from jury service.

One way to reduce the number of potential special jurors excused for financial reasons would be to pay special jurors more-perhaps as much as $\$ 100$ or $\$ 200$ per day. The obvious drawback to such a plan would be the increased expense. Jury costs for a sixmonth trial at $\$ 200$ per juror per day easily could reach $\$ 300,000$. Although there probably would not be many special jury trials, the government may not want to assume such a potentially crushing financial burden. The parties could bear the increased cost of a special jury trial, but this path should be discouraged. Access to special juries ought not to depend on the litigant's ability to pay for the privilege. It is hoped that the procedures for special jury selection outlined in this Note would proride a sufficient supply of potential special jurors for whom service would not be an economic hardship. If events prove otherwise, it may be necessary to devise some means for increased remuneration of special jurors.

126. 28 U.S.C. $\$ 1870$ (1976). 
the court's time and energy would not be required until the actual voir dire. In addition, it would not be necessary to summon dozens of people only to excuse them from service because of the length of the trial. The jury selectors would know to search for competent jurors from among the ranks of government, academia, retired business and professional people, and other groups for whom extended jury service would not constitute an excessive burden. The problem with this approach would be its vulnerability to charges of impropriety in the selection criteria. The court would have to exercise strictest supervision over the jury selectors to ensure that those summoned for jury duty represented as broad a cross section of the community as possible.

Despite the drawbacks, each of these schemes presents a workable means for summoning special jurors. Neither procedure would systematically exclude any cognizable group from jury service, yet both would assure a ready supply of competent jurors for complex cases. ${ }^{127}$ The special jury selection process thus would employ reasonable classifications related to a juror's ability without any impermissible discrimination.

\section{Conclusion}

Complex civil litigation presents many problems for judicial administration that can, in part, be satisfied by the use of special juries. Such juries are constitutionally acceptable because they comport with the historical requirements of the Seventh Amendment and the requirements of due process. Moreover, in some instances, trial by a traditional jury or by a judge does not satisfy these requirements and the special jury is a superior alternative. If chosen with strict observance of constitutional requirements and prudently administered, the special jury can be $a^{\prime}$ constitutional, workable, and desirable solution to the problems of trying complex cases.

127. It is possible that a case requiring a special jury would be brought in a remote or sparsely populated district in which qualified individuals would be difficult if not impossible to find. Such a situation should be considered as grounds for a motion for change of venue. See id. $\$ 1404$. It should be noted, however, that all cases in which the question of jury competence has been raised have been in major metropolitan areas. See, e.g., Zenith Radio Corp. v. Matsushita Elec. Indus. Co., 478 F. Supp. 889 (E.D. Pa. 1979) (Philadelphia); ILC Peripherals Leasing Corp. v. International Business Machs. Corp., 458 F. Supp. 423 (N.D. Cal. 1978) (San Francisco). 